\title{
Tubular lesions in streptozotocin-diabetic rats
}

\author{
R. Rasch \\ Department of Cell Biology, Institute of Anatomy, University of Aarhus, Aarhus, Denmark
}

\begin{abstract}
Summary. Renal tubular lesions have been studied in streptozotocin-diabetic rats after 50 days of diabetes and compared with age-matched controls. The kidney weight increased by $67 \%$ in the diabetic animals and the length of the proximal tubules increased by $22 \%$, but no abnormalities were found. The length of the distal tubules increased by $20 \%$ and the total increase was due to abnormal distal tubules. These abnormalities were confined to the cortex and the outer stripe of the outer medulla, but they were not seen in the inner stripe of the outer medulla. Abnormal cells were found also in the distal tubular cells of the macula densa. The total length of the collecting ducts was the same in the two groups and the cells ap-
\end{abstract}

peared normal. The cells of the abnormal distal tubules appeared either empty or full of a PAS-positive material, digestable with $\alpha$-amylase. At the electron microscope level, the cytoplasm of the cells contained glycogen-like granules, strikingly few organelles and the basal infoldings were greatly reduced. It is suggested that these tubular lesions might play a role in the development of renal functional changes in diabetes.

Key words: Rat, kidney, streptozotocin diabetes, tubular lesions.
The Armanni-Ebstein [1, 7] lesion of diabetic tubules, known since the last century, has attracted so little attention that its exact localization in the nephron is not yet known. The introduction of insulin made the appearance of the lesion more rare [5], but it is, however, also found in insulin-treated patients [24]. In man, it is generally agreed that the lesion is most pronounced at the corticomedullary border $[7,8,22]$, but otherwise its localization has been a matter of controversy. Oliver [16] and Ritchie and Waugh [22] located the diabetic tubular lesion in the terminal part of the proximal convolution. Their observations were based on iron haematoxylinstained isolated nephrons prepared from hydrochloric acid-digested microdissected kidneys, where only gross structural distortions can be observed. Distension and vacuolisation of part of the proximal tubule was observed and also a lighter staining of the cell cytoplasm in the terminal broad ascending limb of Henle's loop. In addition, Oliver [16] and Ritchie and Waugh [22] studied sections of immersion fixed PAS-stained tissue, but identification of the various parts of the nephron was uncertain in these preparations. Based on similar sections Ebstein [7] confined the diabetic tubular lesion to the loop of Henle and Armanni [1] to the collecting duct.
Tubular lesions have also been noticed in experimentally diabetic animals in light microscopic sections of immersion fixed tissue [2, 13, 23]. Arison et al. [2] described the lesion to be located in the proximal tubules, whilst Oliver [16] found them to be in the distal tubules just before the convoluted part. At the electron microscope level, glycogen-like granules have been described in tubules from diabetic patients and also in experimental diabetic animals $[19,20]$.

Tubular structures are optimally preserved applying perfusion fixation [14] and they can be easily identified on Epon embedded sections at the light microscope level. Using perfusion-fixed kidneys from streptozotocindiabetic animals, the present study was undertaken to locate the tubular lesion precisely and to determine the extent of the lesion. In addition, abnormal tubular cells were evaluated at the ultrastructural level.

\section{Materials and methods}

Two groups of female Wistar rats with an initial body weight of $120 \pm 5 \mathrm{~g}$ (mean $\pm \mathrm{SD}$ ) were followed up for 50 days. Diabetes was induced in five rats by intravenous injection of $90 \mathrm{mg}$ streptozotocin $/ \mathrm{kg}$ body weight. The animals were left without insulin treatment. Blood glucose was measured once a week with Dextrastix (Ames, Slough, 
Table 1. Body and kidney weight in the diabetic and non-diabetic rats studied

\begin{tabular}{lccc}
\hline & $\begin{array}{l}\text { Non-diabetic rats } \\
(n=5)\end{array}$ & $\begin{array}{l}\text { Diabetic rats } \\
(n=5)\end{array}$ \\
\hline $\begin{array}{l}\text { Body weight before the } \\
\text { experiment }(\mathrm{g})\end{array}$ & $120 \pm 6$ & $123 \pm 5$ \\
$\begin{array}{l}\text { Body weight after 50 days }(\mathrm{g}) \\
\begin{array}{l}\text { Kidney weight after } \\
50 \text { days }(\mathrm{g})\end{array}\end{array}$ & $\begin{array}{c}217 \pm 13 \\
0.92 \pm 0.07\end{array}$ & $177 \quad$\begin{tabular}{c}
$1.54 \pm 0.15$ \\
\hline
\end{tabular}
\end{tabular}

Results are expressed as mean $\pm \mathrm{SD}$. Kidney weight represents the mean of both kidneys after 50 days

Table 2. Kidney zones expressed as percentage areas of the total kidney. Fractional areas in percentage of the total kidney

\begin{tabular}{lcl}
\hline Zone & $\begin{array}{l}\text { Non-diabetic rats } \\
(n=5)\end{array}$ & $\begin{array}{l}\text { Diabetic rats } \\
(n=5)\end{array}$ \\
\hline Cortex & $50 \pm 3$ & $50 \pm 3$ \\
Outer medulla (outer stripe) & $29 \pm 2$ & $29 \pm 4$ \\
Outer medulla (inner stripe) & $16 \pm 0.5$ & $17 \pm 0.5$ \\
Inner medulla & $5 \pm 0.3$ & $4 \pm 0.3$ \\
\hline
\end{tabular}

Results are expressed as mean $\pm \mathrm{SD}$

Table 3. Total tubular length in various zones of the kidney

\begin{tabular}{lcll}
\hline & \multicolumn{2}{l}{$\begin{array}{l}\text { Length of parts of the nephron } \\
(\mathrm{m} / \text { kidney })\end{array}$} & \\
\cline { 2 - 4 } & $\begin{array}{l}\text { Non-diabetic } \\
\text { rats }(n=5)\end{array}$ & $\begin{array}{l}\text { Diabetic rats } \\
(n=5)\end{array}$ & $2 p$ \\
\hline $\begin{array}{l}\text { Proximal tubules } \\
\text { Normal distal tubules }\end{array}$ & $272 \pm 17$ & $331 \pm 14$ & 0.0004 \\
$\begin{array}{c}\text { Abnormal distal tubules } \\
\text { (cortex) }\end{array}$ & 0 & $202 \pm 38$ & NS \\
$\begin{array}{c}\text { Abnormal distal tubules } \\
\text { (outer medulla, outer } \\
\text { stripe) }\end{array}$ & 0 & $26 \pm 3$ & \\
Collecting ducts & $64 \pm 12$ & $65 \pm 16$ & NS \\
\hline
\end{tabular}

Results are given as mean \pm SD

UK) applying an Ames reflectancemeter (Ames, Tokyo, Japan) and the urine was tested for ketone bodies once a week with Ketostix (Ames, Slough, UK). A control group consisted of five animals. After 50 days, perfusion-fixation was performed with $1 \%$ glutaraldehyde in a modified Tyrode solution, containing only three-quarters of the usual $\mathrm{NaCl}$ concentration [14]. The fixative was infused retrograde through the aorta with a pressure of $140 \mathrm{mmHg}$. The structural preservation of the tissue to be studied was ascertained by immediate bleaching of the kidneys after the start of the perfusion.

The right kidneys were cut in 10-14 horizontal slices applying an instrument with razor blades fixed $1 \mathrm{~mm}$ apart. These cross-sections were embedded in paraffin and one section from the middle of each slice was stained with PAS. All sections were used for determination of volume fractions of cortex, outer stripe of the outer medulla, inner stripe of the outer medulla and inner medulla. The relative areas were estimated applying a point count technique to sections projected onto a screen [9]. The cortex was defined as the area containing glomeruli. The outer stripe of the outer medulla was the area below the cortex containing proximal tubules. The inner stripe of the outer medulla was the area containing the thick ascending limb of the loop of Henle, but not the proximal tubules. The inner medulla was the papillary area not containing distal tubules.
The left kidneys were weighed and cut into $1 \mathrm{~mm}$ slices as described above. From the central slice containing the papilla, five randomized blocks of tissue were cut from each of the following zones: cortex, outer stripe of the outer medulla, inner stripe of the outer medulla and the inner medulla. Cubic tissue blocks were postfixed in osmium tetroxide for $1 \mathrm{~h}$, dehydrated in alcohol and embedded randomly orientated in gelatine capsules filled with Epon (Taab, Reading, UK). Sections $(1 \mu \mathrm{m})$ were cut on an Ultrotome III (LKB, Stockholm, Sweden), stained with PAS and counterstained with toluidine blue. The sections were projected onto a screen with a final magnification of 400 . Assuming homogeneity within the different kidney zones the total length of proximal tubules, distal tubules, collecting ducts and pathologically altered tubules could be calculated from these sections. In the present study, the distal tubules included the thick ascending limb of the loop of Henle.

The volume fraction $\left(V_{v}\right)$ of the various kidney zones was estimated applying a point count technique on the paraffin embedded sections. From these data and from counting the number of tubular profiles within a randomly placed counting frame [10] on Epon embedded sections, the total tubular length was calculated. The length per unit volume of tubular structure was estimated according to Weibel [29] using $2 \times$ NA, where NA is the number of tubular profiles per unit area in the various kidney zones. The total tubular length in the different zones from one kidney can be expressed as: $2 \times \mathrm{NA} \times \mathrm{V}_{\mathrm{v}} \times$ kidney weight.

Epon embedded sections ( $1 \mu \mathrm{m}$ thick) were treated with $\mathrm{KOH}$ dissolved in $99 \%$ alcohol $(1: 9)$ for $1 \mathrm{~h}$, partially to remove the Epon. Subsequently, the sections were treated for $17 \mathrm{~h}$ with either an unboiled or a boiled 4\% $\alpha$-amylase (British Drug Houses, Pool, Dorset, UK) solution and finally PAS-stained.

Light microscopy was performed on 25 tubules containing one or a few abnormal cells where the remaining normal tubular cells made the identification of the profile definite. Light microscopy also was performed on the same number of proximal tubular- and collectingduct profiles.

In each animal electron microscopy was performed on 10 tubules that were also studied by light microscopy.

The two-tailed Student's t-test for unpaired samples was used for statistical analyses.

\section{Results}

After 50 days, the diabetic animals had gained less weight than the non-diabetic animals (Table 1). During the experimental period, the diabetic animals had blood glucose levels of $22 \pm 1 \mathrm{mmol} / 1$ (mean $\pm \mathrm{SD}$ ). The kidney weight of the diabetic animals was $61 \%$ greater than in non-diabetic animals (Table 1), but the relative volumes of the various kidney regions measured on paraffin embedded sections remained unchanged (Table 2). Estimated from sections of Epon-embedded tissue, the length of the proximal tubules increased significantly $(22 \pm 1 \%$; mean $\pm \mathrm{SD}, 2 p=0.0004)$. The cells of all three proximal segments appeared normal, both by light and electron microscopy. The length of normal distal tubules and collecting ducts were the same in both groups (Table 3). However, in addition, diabetic animals had abnormal tubules with a mean total length of $65 \mathrm{~m}$ (Table 3).

Light microscopy of the pathologically-changed cells showed that they did not have a brush border and did not contain lysosomes or endocytic vacuoles as characteristically seen in the proximal tubules (Figs. $1 \mathrm{~A}$, 2,5 ). Electron microscopy revealed that the abnormal 


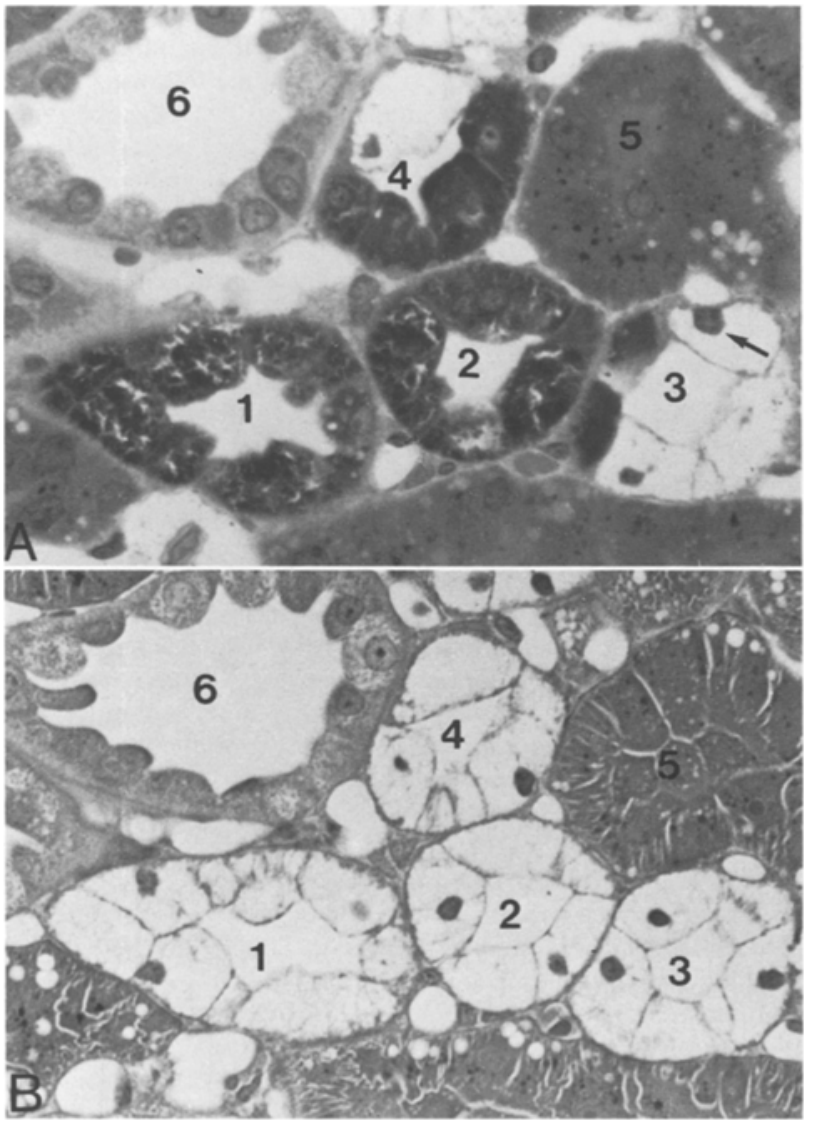

Fig. 1A and B. Light micrograph of Epon embedded serial sections $(1 \mu \mathrm{m}$ thick) of four distal tubules stained with PAS and counterstained with toluidine blue. A Some of the abnormal PAS-positive distal tubular cells appear black $(1,2)$, others are partially empty $(3,4)$ except for the nucleus (arrow). B Section treated with $\alpha$-amylase prior to the PAS-staining. The same tubular cells all appear empty. Proximal tubules (5), collecting duct $(6) .(\times 400)$

cells always had an intact cell membrane with few rounded microvilli on the surface. The extensive basal infoldings of the cell membrane of normal distal tubular cells, comprising about two-thirds of the cell height (Fig. 3A), was reduced to a cell membrane running nearly parallel to the basal lamina (Fig. $3 \mathrm{~B}$ ). The cytoplasm of the abnormal cells contained strikingly few organelles, mostly located close to the nucleus or the cell membrane. The majority of the remaining organelles were mitochondria. The cytoplasm of most abnormal cells was loaded with large diffusely distributed granules (20-35 nm), resembling glycogen particles (Fig. 4). The cytoplasm of some of the abnormal cells appeared empty, but the nucleus was still present (Fig.1A). In PAS-stained Epon embedded sections treated with the alcoholic KOH solution, the cytoplasm of most abnormal tubular cells was PAS-positive with bright red cytoplasm. The PAS staining was totally prevented by the $\alpha$ amylase digestion (Fig.1A and B). Application of boiled diastase did not alter the PAS staining.

The abnormal tubules were located in the cortex and in the outer stripe of the outer medulla. The distal

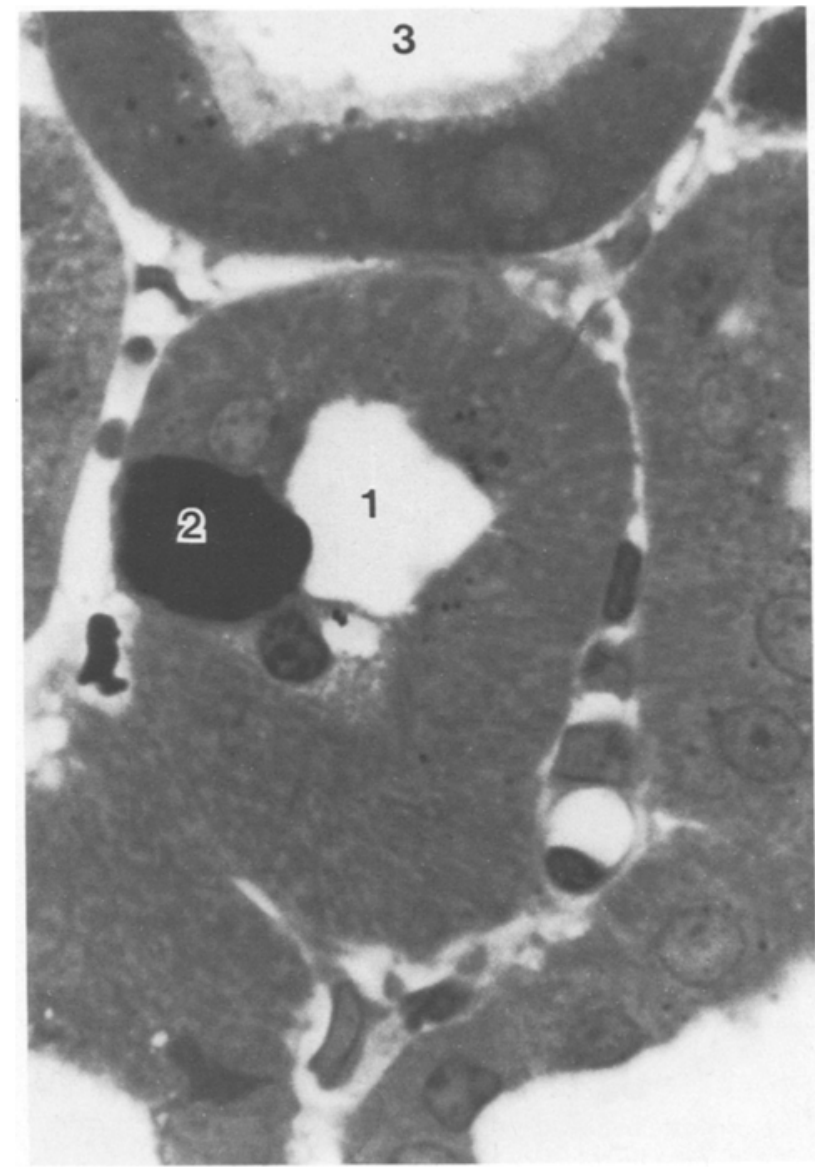

Fig. 2 Light micrograph of Epon embedded section (1 $1 \mathrm{~m}$ thick), PAS-stained and counterstained with toluidine blue. Distal tubule (1) with one abnormal PAS-positive cell (2), here appearing black. Proximal tubule $(3) .(\times 1,000)$

tubule passing the glomerulus and forming the macula densa frequently contained many abnormal cells in its epithelium (Fig.5). In partially abnormal tubular profiles, containing one or a few abnormal cells, the remaining tubular cells could always be identified indisputably as distal tubular cells (Fig. 2). Abnormal cells have neither been observed in profiles containing proximal tubular cells nor in connection with cells of collecting ducts.

\section{Discussion}

The present investigation has shown very pronounced abnormalities in tubular cells in streptozotocin-diabetic rats after 50 days duration of diabetes. The investigations have disclosed that the pathologically changed tubules were found in the cortex and in the outer stripe of the outer medulla, and that most of the abnormal cells were located in the latter zone. The localization of the abnormalities to the distal tubules is strongly suggested by the appearance of only partially changed distal tu- 


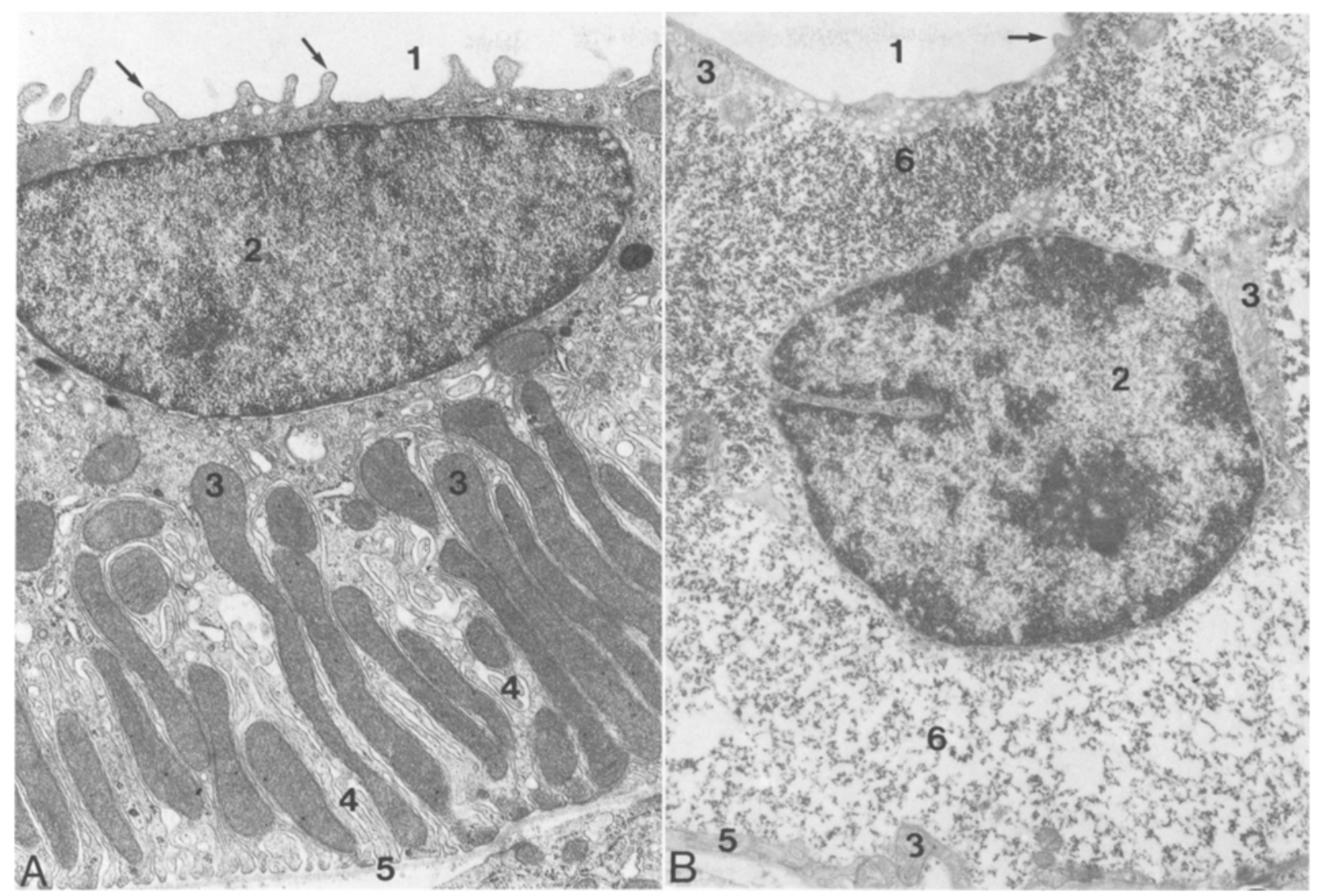

Fig. 3. A Electron micrograph of a normal distal tubular cell, showing a large amount of slender mitochondria (3) along the deep infoldings of the basal cell membrane (4). (1) lumen with microvilli (arrows). B Abnormal distal tubular cell. The amount of mitochondria (3) is very sparce and no basal infoldings are seen. The cytoplasm of the cell is filled with $\beta$-glycogen particles (6). Towards the lumen one microvillus is seen (arrow). Nucleus $(2)$, basal lamina $(5) .(\times 8,500)$

bules and by the frequent abnormalities found in the macula densa region where distal tubules can be positively identified. This localization is further supported by the absence of abnormalities in the inner medulla where only collecting ducts are present but not distal tubules and by the observation that no abnormalities were seen in the proximal tubules or in the collecting ducts. Furthermore, the proximal tubules increased in length by $22 \%$, which in the diabetic animals corresponds to the sum of distal tubular length and the length of abnormal tubules $(20 \%)$.

Previous descriptions of localization of the diabetic tubular lesion in the nephron are contradictory. In the digested and microdissected nephron [16, 22], the cellular structures are poorly preserved and it is uncertain whether the PAS-positive material found on histological sections were actually located in the dilated and vacuolized parts of the dissected nephrons. The histological studies in man were all performed on post mortem immersion-fixed tissue $[1,7,8,16]$ or biopsies $[5,19]$ in which tubular structures are poorly preserved and are difficult to identify. The present description of the individual altered tubular cells is more in accordance with earlier descriptions, where under the light microscope cells were vacuolized $[1,7]$ and stainable with iodine [8].
At the electron microscopic level, these cells have been described to contain a granular material in the cytoplasm $[2,5,20]$. In contrast to these observations $[2,5$, $20]$ and to the findings in the present study, Orci et al. $[17,19]$ described glycogen-like particles to be located in membrane-bound organelles, probably lysosomes, in experimentally induced diabetes.

The disappearance of the PAS-positive material in abnormal cells by application of $\alpha$-amylase confirms its carbohydrate nature. This evidence was further supported by electron microscopy, which revealed that the PAS-positive cells observed in the light microscope were loaded with particles of the same size as monoparticulate $\beta$-glycogen [4].

The mechanism leading to glycogen accumulation in kidney tubules in diabetes is obscure. The tubular cells are exposed to increased glucose concentrations from both the basal and luminal side, but the possible influence on synthesis and accumulation of glycogen in the kidney tubular cells is as yet unknown. Normally glucose reabsorption takes place in the first part of the proximal tubule [28] and little glucose is absorbed in the distal parts of the nephron [26], which normally is exposed to low glucose concentrations from the luminal side. By induction of hyperglycaemia, glucose can, 


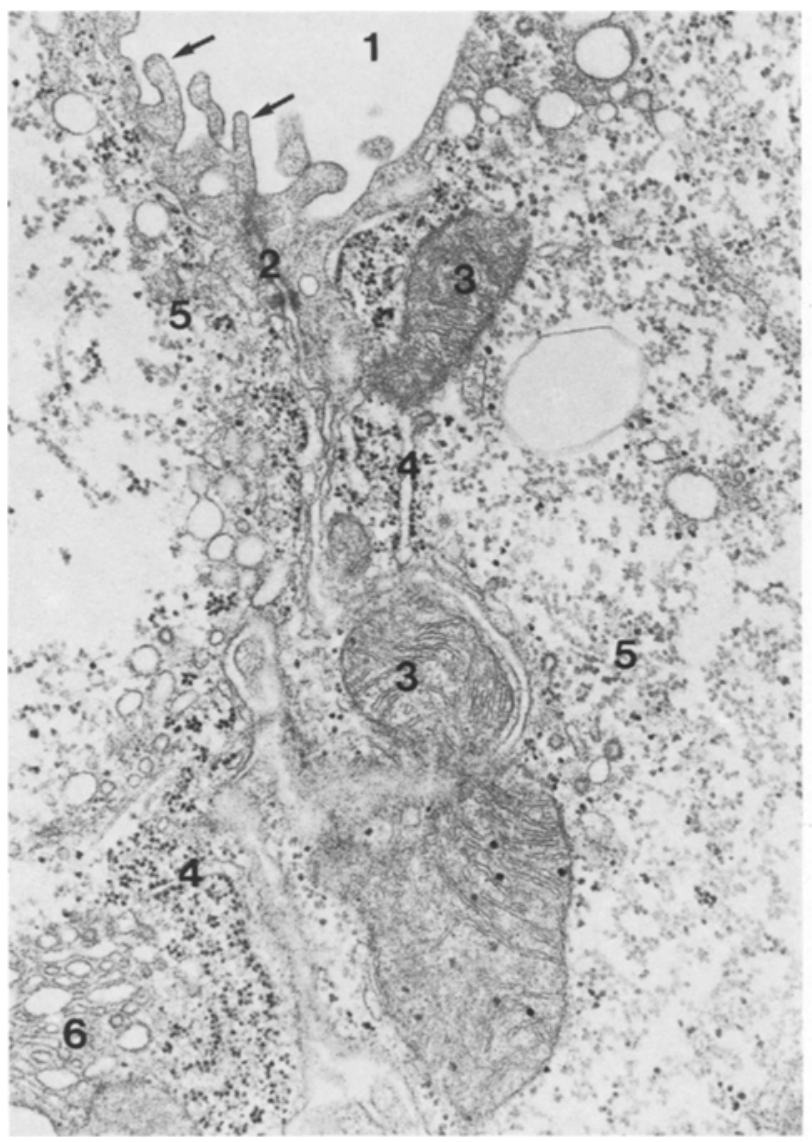

Fig.4. Electron micrograph at a higher magnification of part of two abnormal adjacent tubular cells. Tubular lumen (1), junction between two cells (2), mitochondria (3), endoplasmic reticulum with ribosomes (4) which appear darker than the glycogen particles (5), Golgi complex $(6) .(\times 20,000)$

however, be taken up from the more distal parts of the nephron [3].

The energy released by glucose oxidation in the distal tubule is mainly used for maintaining the energyconsuming sodium-potassium pump [25] as the concentration of sodium-potassium-activated adenosine triphosphatase $/ \mathrm{mm}$ tubule length is higher in the distal compared with the proximal tubule. In distal tubular cells from normal rats, sodium-potassium-activated adenosine triphosphatase is localized in the cell membrane of the large and numerous basal infoldings, which are in close contact with the mitochondria. In our diabetic rats, the basal infoldings had almost totally disappeared from the abnormal distal tubular cells, which implies abnormal sodium-potassium transport in pathological cells.

The appearance of abnormal cells is undoubtedly due to the diabetic state of which nephromegaly is a part, except in severly diabetic animals [27]. In nephromegaly induced by factors other than diabetes, pathologically changed tubules have not been observed [21].

A characteristic finding in the diabetic kidney in both man $[6,15]$ and experimental animals $[6,11,12]$ is an increased glomerular filtration rate. The mechanism

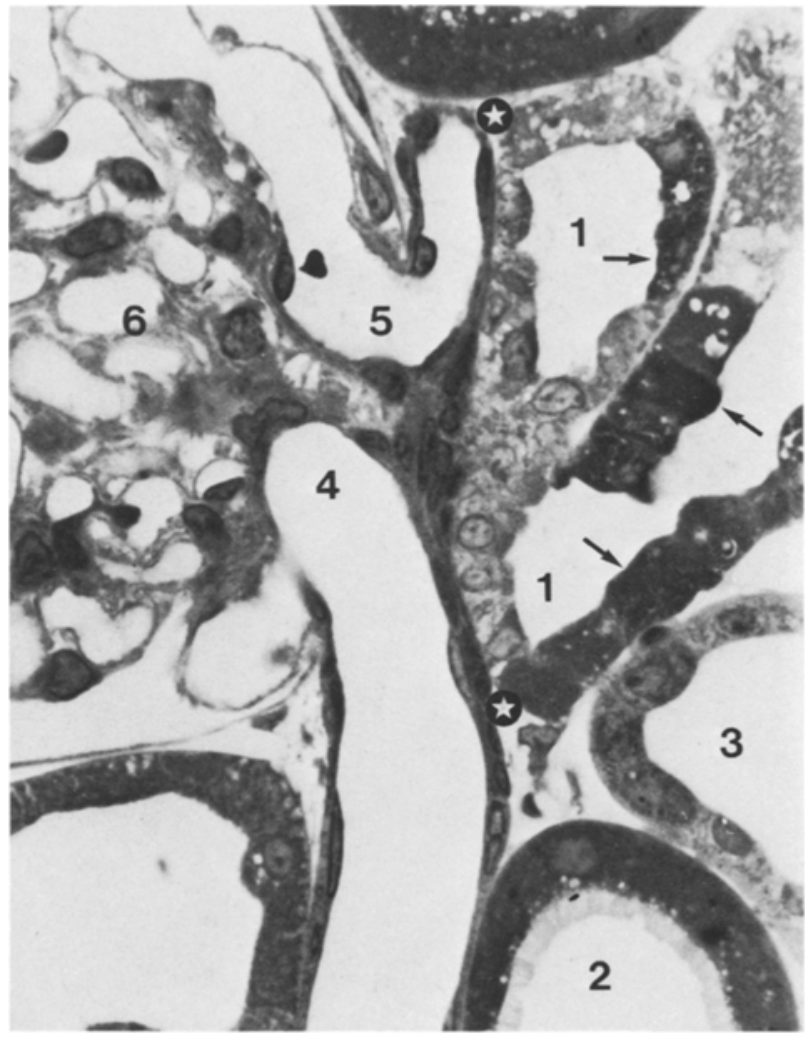

Fig.5 Light micrograph of an Epon embedded juxtaglomerular apparatus $(1 \mu \mathrm{m}$ thick) stained with PAS and counterstained with toluidine blue. A distal tubule (1) winds up to the glomerulus and forms a macula densa $\downarrow$ to $\star$. Several of the distal tubular cells are abnormal and appear much darker (arrows) than the normal distal tubular cells. Proximal tubule (2), collecting duct (3), afferent arteriole (4), efferent arteriole (5), glomerular tuft $(6) .(\times 350)$

behind an elevated glomerular filtration rate in diabetes is not fully known, although various theories have been proposed $[6,11]$. The present investigation, demonstrating extensive damage of distal tubules in diabetes, including macula densa, adds a new factor to be considered when exploring abnormal glomerular function. However, whether distal tubular changes cause glomerular functional changes or whether both changes are part of the same process needs to be evaluated further.

Acknowledgements. I am grateful to Mrs. B. Overgaard for expert technical assistance. The study was supported by the Danish Medical Research Council and by Novo.

\section{References}

1. Armanni L (1877) Fünf Autopsien mit histologischen Untersuchungen und klinischer Epicrise. In: Cantani A (ed) Der Diabetes Mellitus, vierzehnte Vorlesung. Denickes Verlag, Berlin, pp 315-329

2. Arison RN, Ciaccio EI, Glitzer MS, Cassaro JA, Pruss MP (1967) Light and electron microscopy of lesions in rats rendered diabetic with streptozotocin. Diabetes 16: 51-56

3. Bayer HV, Haeberte DA, Van Liew JB, Hare D (1980) Glomerular 
tubular balance of renal D-glucose transport during hyperglycaemia. Pflügers Arch 384: $39-47$

4. Biavia C, Grossman A, West M (1966) Ultrastructural observations on renal glycogen in normal and pathologic human kidneys. Lab Invest 15: 330-356

5. Ditscherlein $G$ (1969) Nierenveränderungen bei Diabetikern. VEB Gustav Fischer, Jena, pp 25-27

6. Ditzel J, Junker K (1972) Abnormal glomerular filtration rate, renal plasma flow and renal protein excretion in recent and shortterm diabetics. Br Med J II 13-20

7. Ebstein W (1881) Über Drüsenepithelnekrosen beim Diabetes Mellitus mit besonderer Berticksichtigung des diabetischen $\mathrm{Co}$ ma. Dtsch Arch Klin Med 30: 143-185

8. Ehrlich D (1883) Über das Vorkommen von Glycogen im diabetischen und im normalen Organismus. 2 Klin Med 6: 33-46

9. Elias H, Henning A, Schwartz DE (1971) Stereology: application to biomedical research. Physiol Rev 51: 158-200

10. Gundersen HJG (1977) Notes on the estimation of the numerical density of arbitrary profiles: the edge effect. $\mathbf{J}$ Microscopy 111 : 219-223

11. Hostetter TH, Troy JL, Brenner BM (1981) Glomerular hemodynamics in experimental diabetes mellitus. Kidney Int 19:410-415

13. Mauer SM, Sutherland DER, Steffes MW, Leonard RJ, Najarian JS, Michael AF, Brown DM (1974) Pancreatic islet transplantation (effects on the glomerular lesions of experimental diabetes in the rat). Diabetes 23: 748-753

14. Maunsbach AB (1966) The influence of different fixatives and fixation methods on the ultrastructure of rat proximal tubule cells. J Ultrastruct Res 15: 283-309

15. Mogensen CE, Andersen MJF (1973) Increased kidney size and glomerular filtration rate in early juvenile diabetes. Diabetes 22: $706-712$

16. Oliver J (1944) New directions in renal morphology: a method, its results and its future. The Harvey Lectures. Sci Press 40: 102-105

17. Orci L, Stauffacher W (1971) Glycogenosomes in renal tubular cells of diabetic animals. J Ultrastruct Res 36: 499-503

18. Orci L, Stauffacher W, Amherdt M, Pictet R, Renold AE, Rouiller CH (1970) The kidney of spiny mice. Diabetologia 6: 343-355
19. Ormos J, Solbach H-G (1973) Beitrag zur Morphologie der Niere bei Diabetes mellitus. Frank Z Pathol 72:379-418

20. Powel HC, Ward HW, Garrett RS, Orloff MJ, Lampert PW (1979) Glycogen accumulation in the nerves and kidney of chronically diabetic rats. J Neurol Exp Neuropathol 20: 114-127

21. Rasch R, Nørgaard JOR (1983) Renal enlargement: comparative autoradiographic studies of ${ }^{3} \mathrm{H}$-Thymidine uptake in diabetic and uninephrectomized rats. Diabetologia 25: 280-287

22. Ritchie S, Waugh D (1957) The pathology of Armanni-Ebstein diabetic nephropathy. Am J Pathol 33: 1035-1057

23. Robbins SL (1950) The reversibility of glycogen nephrosis in alloxan-treated diabetic rats. Am J Med Sci 219:376-381

24. Robbins SL, Tucker AW (1944) The cause of death in diabetes. N Engl $J$ Med 231: 865 -868

25. Ross BD, Bullock S, Frega N, Leaf A (1978) Glucose as a fuel in the kidney. Biochem Soc Trans 6:524-526

26. Schmidt U, Guder WG (1976) Sites of enzyme activity along the nephron. Kidney Int 9: 233-242

27. Seyer-Hansen K (1978) Renal hypertrophy in experimental diabetes: a comparison to compensatory hypertrophy. Diabetologia 14 : $325-328$

28. Silvermann $M$ (1981) Glucose reabsorption in the kidney. Can J Physiol 59: 209-224

29. Weibel ER (1973) Stereological techniques for electron microscopic morphometry. In: Hayat MA (ed) Principles and techniques for electron microscopy, vol 3. Van Nostrand Reinhold, New York, pp 239-296

Received: 4 May 1983

and in revised form: 4 May 1984

Dr. R. Rasch

Department of Cell Biology

Institute of Anatomy

University of Aarhus

DK- 8000 Aarhus C

Denmark 